\title{
Telomerase as a new target for the treatment of hormone-refractory prostate cancer
}

\author{
Annamaria Biroccio and Carlo Leonetti
}

Experimental Chemotherapy Laboratory, Regina Elena Cancer Institute, Via delle Messi d'Oro 156, 00158 Rome, Italy

(Requests for offprints should be addressed to C Leonetti; Email: leonetti@ifo.it)

\begin{abstract}
Prostate cancer is the leading cause of cancer-related deaths in men. Androgen ablation is the mainstay of treatment for advanced prostate cancer. This therapy is very effective in androgen-dependent cancer; however, these cancers eventually become androgen independent, rendering anti-androgen therapy ineffective. The exploration of novel modalities of treatment is therefore essential to improve the prognosis of this neoplasia.

Telomeres are specialized heterochromatin structures that act as protective caps at the ends of chromosomes. Telomere maintenance in the majority of tumor cells is achieved by telomerase, a reverse transcriptase enzyme that catalyzes the synthesis of further telomeric DNA. Telomerase is detected in the majority of prostate cancers, but not in normal or benign prostatic hyperplasia tissue. Moreover, the human telomerase reverse transcriptase (hTERT) gene, the catalytic subunit of telomerase, is regulated by androgens as well as by different oncogenes including Her-2, Ras, c-Myc and $\mathrm{Bcl}-2$, which seem to play an important role in prostate cancer progression. Thus, telomerase may represent a very good candidate for targeted therapy in prostate tumors. To inhibit telomere maintenance by telomerase, approaches that directly target either telomerase and telomeres or the telomerase regulatory mechanisms have been used. Moreover, strategies targeting telomerase-positive cells as a means to directly kill the tumor cells have been tested. This review summarizes the most promising results achieved by anti-telomerase strategy in different solid tumors. Most of the telomeraseassociated therapies described here have proved very promising for the treatment of prostate cancer. On the basis of the good results obtained and considering the multigenic defects of human tumors, including prostate cancer, the combination of anti-telomerase strategies with conventional drugs and/or molecules capable of interfering with oncogenic pathways could efficiently improve the response of this neoplasia.
\end{abstract}

Endocrine-Related Cancer (2004) 11 407-421

\section{Introduction}

Prostate cancer is the most frequently diagnosed malignancy, apart from skin cancers, in developed countries, and is a leading cause of cancer-related deaths in men (Feldman $\&$ Feldman 2001). The risk of prostate cancer rises with age and continues to increase by 3-4\% each year as fewer men die from cardiovascular disease. Androgen ablation is the leading treatment and currently the most successful for progressive prostate cancer. However, due to the emergence of androgen-independent cells, tumors have become insensitive to this kind of treatment (Denmeade \& Isaacs 2002). Continuous effort is therefore required to find new targets for therapeutic intervention of androgen-independent prostate cancer.

One of the most common causes by which prostate tumors have become androgen independent is the amplification of the androgen receptor gene. It has been reported that about $30 \%$ of tumors exhibiting androgen independence after ablation therapy shows overexpression of the androgen receptor (Koivisto et al. 1997, Linja et al. 2001). Amplified levels of the androgen receptor are 
accompanied by an increased sensitivity to the androgens. The dose of androgen necessary to stimulate cell proliferation in androgen-independent cancer cells is therefore significantly lower than that observed in androgen-dependent cancer cells (Culig et al. 1999, Gregory et al. 2001a).

The switch from androgen-dependent to -independent tumors has also been associated with an increase in the mutation frequency of the androgen receptor. When the androgen receptor is wild type it is specifically activated by testosterone and dihydrotestoterone, while androgen receptor mutations give broadened ligand specificity and the mutated receptor can also be stimulated by glucorticoids and flutamide (Taplin et al. 1999, Zhao et al. 2000, Hara et al. 2003).

The transcriptional activity of the androgen receptor is normally modulated by co-regulatory proteins. It has been reported that the onset of recurrent prostate cancer growth after androgen ablation therapy might result from the overexpression of coactivators, such as the two nuclear receptor coactivators, transcriptional intermediary factor 2 and steroid receptor coactivator 1 (Gregory et al. 2001b). Overexpression of these coactivators increases androgen receptor transactivation and enhances responses to low levels of androgen.

A number of molecular genetic changes have also been associated with the increased proliferation and/or apoptosis inhibition in prostate tumors in the absence of androgens or the androgen receptor. In particular, it has been demonstrated that Her-2 overexpression enhances the interaction between the androgen receptor and coactivators, thus indicating a role for aberrant expression of Her-2 in prostate carcinogenesis as well as progression to androgen-independent growth (Yeh et al. 1999). Constitutive activation of the Ras/MAP kinase pathway correlates with hormone refractory tumor growth (Bakin et al. 2003) and it has been associated with advanced grade and stage of prostatic tumors (Gioeli et al. 1999). Inhibition of apoptosis by bcl-2 oncogene is suggested as another mechanism by which prostate tumors escape from androgen ablation therapy (Miyake et al. 1999, 2001). Negative staining of Bcl-2 was found in benign prostatic hyperplasia, while Bcl-2 positivity was observed in premalignant prostatic intra-epithelial neoplasia, which is considered the primary precursor of human prostate cancer (McDonnell et al. 1992, Raffo et al. 1995). Finally, overexpression and/or amplification of the c-myc gene have been observed in about $70 \%$ of androgen-independent prostate cancers (Nupponen et al. 1998, Nupponen \& Visakorpi 2000). The c-Myc-dependent prostate cancer cell proliferation appears to be androgen independent, since the reduction of androgen receptor expression is ineffective in prostate tumors overexpressing c-Myc (Bernard et al. 2003). All these findings indicate that beyond the alterations in the androgen-dependent pathway, other mechanisms are involved in prostate cancer progression.

\section{Telomerase in prostate cancer}

Telomeres are specialized heterochromatin structures that act as protective caps at the ends of chromosomes. Human telomeres consist of tandem repeats of the hexanucleotide sequence TTAGGG in double strand, except for a terminal 3' G-rich overhang (McElligot \& Wellinger 1997, Makarov et al. 1997, Wright et al. 1997). In normal somatic cells, telomeres shorten with each round of cell division and, when they reach a critically short length, cells exit from the cell cycle and undergo a replicative senescence. By contrast, immortal cells as well as germline cells adopt some mechanisms to bypass the senescence checkpoint. Telomere maintenance in 80-95\% of tumor cells is achieved by telomerase, a reverse transcriptase enzyme that catalyzes the synthesis of further telomeric DNA repeats.

The telomerase holoenzyme consists of the catalytic subunit reverse transcriptase protein hTERT (Nakamura et al. 1997), the telomerase RNA template subunit, hTR (Feng et al. 1995) and other associated proteins (Harrington et al. 1997).

Telomerase activity is typically absent from most normal human cells, but is expressed in nearly all human cancer cells (Kim et al. 1994, Broccoli et al.1995, Hiyama et al.1995a). In prostate tissue, telomerase activity has not been found in normal samples or benign prostatic hyperplasia tissues, while primary prostate cancers exhibit high levels of telomerase activity (Sommerfeld et al. 1996, Lin et al. 1997). In agreement with these results, hTERT immunoreactivity was found in high-grade prostate tumors (Gleason score >4) (Iczkowski et al. 2002). Since it has been demonstrated that androgen depletion activated telomerase in the prostate of monkeys, the negative regulation of telomerase activity by androgen is probably lost during prostate tumorigenesis (Ravindranath et al. 2001).

Telomerase activity has also been correlated with prostate tumor aggressiveness. In particular, compared with low grade tumors, high grade tumors have maximally activated telomerase and a significant correlation between the telomerase activity and the Gleason score has been found (Kamradt et al. 2003). Interestingly, the hTERT gene seems to be regulated by androgens. Administration of androgens to androgen-sensitive LNCaP prostate cancer cells activated the hTERT promoter, while androgen ablation led to a decrease in hTERT expression with a concomitant reduction in telomerase activity which, in turn, was reversed by the 


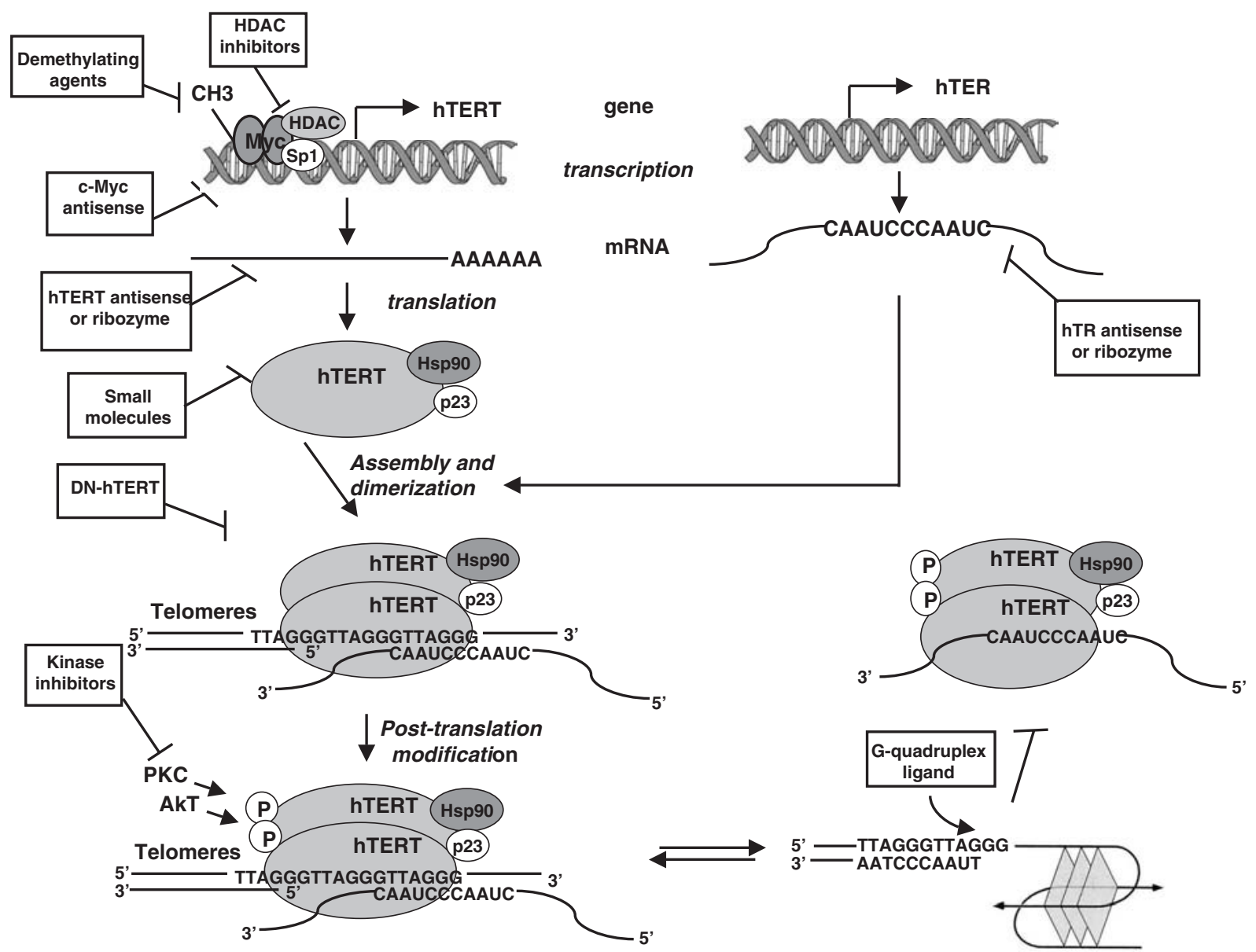

Figure 1 Telomerase is composed of two major components: the catalytic subunit (hTERT) and the template RNA (hTER). Other proteins and kinases are additional components of the holoenzyme. Telomerase activation is achieved by various steps, including transcriptional and post-transcriptional levels of the hTERT. A number of transcriptional factors (i.e. c-Myc) and changes in the chromatin structure (acetylation and methylation) have been implicated in the control of hTERT. Some of the most promising approaches that directly target either telomerase and telomeres or the telomerase-associated regulatory mechanisms are reported in the boxes. HDAC, histone deacetylase; DN-hTER, dominant-negative hTERT; PKC, protein kinase C.

subsequent administration of androgens (Bosland 2003). Consistent with these results, a decline in hTERT immunostaining has been observed in human specimens of prostate cancer after complete ablation therapy and the steepest reduction in telomerase activity was noted in the highest grade tumors (Iczkowski et al. 2004). Moreover, the hTERT gene is regulated by different oncogenes including c-Myc (Wang et al. 1998), Bcl-2 (Mandal \& Kumar 1997), Her-2 and Ras (Goueli \& Janknecht 2004), which seem to play an important role in prostate cancer progression.

All these findings suggest that telomerase might represent a very good candidate for targeted therapy in prostate tumors. Finally, considering the multigenic defects of human tumors, including prostate cancer, the combination of anti-telomerase strategies with conventional drugs and/or molecules capable of interfering with oncogenic pathways might efficiently improve the response of this neoplasia.

This review summarizes the most promising results achieved by anti-telomerase strategies in different tumors, including prostate cancer.

\section{Inhibiting telomerase}

To inhibit telomere maintenance by telomerase, approaches that directly target either telomerase and telomeres or the telomerase-associated regulatory mechanisms have been used (Fig. 1). Moreover, strategies 
targeting telomerase-positive cells as a means of directly killing the tumor cells were tested.

\section{Approaches targeting telomerase and telomeres}

Telomeric DNA and the core telomerase components of telomerase, hTR and hTERT, are definitely required for telomerase function and therefore they are good targets for anti-telomerase strategy. In Table 1 the most promising approaches used to directly target telomerase and telomeres are shown.

\section{$2^{\prime}-5^{\prime}$ oliogoadenylate antisense}

$2^{\prime}-5^{\prime}$ oliogoadenylate antisense (2-5A) strategy has been applied to specifically and efficiently degrade hTR (2-5A anti-hTR). The 2-5 anti-hTR is a chimeric antisense oligonucleotide obtained by linking a 19-mer antisense oligonucleotide targeting hTR to a 2-5A molecule able to recruit and activate the endoribonuclease RNAse $\mathrm{L}$ at the site of the target RNA sequence. The treatment of human prostate cancer cells with $2-5 \mathrm{~A}$ anti-hTR efficiently reduced the cell viability in a very short time exposure (Kondo et al. 2000). Similar anti-tumoral effects following treatment with $2-5 \mathrm{~A}$ anti-hTR were observed in other telomerase-positive tumors, such as malignant glioma, ovarian, bladder and cervical cancer cells (Komata et al. 2000, Kushner et al. 2000, Mukai et al. 2000, Koga et al. 2001a, Yatabe et al. 2002). Interestingly, telomerasenegative astrocytes, endothelial cells or fibroblasts are resistant to the $2-5 \mathrm{~A}$ anti-hTR treatment. The efficacy of 2-5A anti-hTR has also been evaluated in vivo. The results demonstrated that intra-tumoral treatment with 2-5A anti-hTR of prostate, glioma and bladder xenografts produced a significant anti-tumor effect due to apoptosis induction (Kondo et al. 1998, Mukai et al. 2000, Koga et al. 2001a). Moreover, a synergistic anti-tumoral effect was observed by combining the $2-5 \mathrm{~A}$ anti-hTR with the anticancer drug cisplatin or the recombinant adenovirus carrying the p53 tumor suppressor (Komata et al. 2000, Kondo et al. 2001). Therefore, 2-5A anti-hTR represents an effective novel approach for the treatment of telomerase-positive tumors including prostate cancer as a single or combined treatment.

\section{$N 3^{\prime} \rightarrow P 5^{\prime}$ phosphoramidate oligonucleotides}

$\mathrm{N} 3^{\prime} \rightarrow \mathrm{P}^{\prime}$ phosphoramidate oligonucleotides (NP) have been designed, synthesized and evaluated as telomerase inhibitors. NP oligonucleotides were targeted at a segment of hTR downstream from the hTR template region, but

Table 1 Targeting of core telomerase components and telomeric DNA.

\begin{tabular}{|c|c|c|c|c|}
\hline Target & Therapeutic approach & Tumor type & Molecular effects & Biological effects \\
\hline \multirow[t]{4}{*}{$\begin{array}{l}\text { Telomerase } \\
\text { hTR }\end{array}$} & $\begin{array}{l}2^{\prime}-5^{\prime} \text { oliogoadenylate } \\
\text { antisense }\end{array}$ & $\begin{array}{l}\text { Glioma, prostate, } \\
\text { ovarian, bladder } \\
\text { and cervival cancers }\end{array}$ & Telomerase inhibition & $\begin{array}{l}\text { Apoptosis, increased } \\
\text { sensitivity to cisplatin }\end{array}$ \\
\hline & $\begin{array}{l}\mathrm{N}^{\prime} \rightarrow \mathrm{P}^{\prime} \text { thio- } \\
\text { phosphoramidate } \\
\text { oligonucleotides } \\
\text { (GRN163) }\end{array}$ & Prostate cancer & $\begin{array}{l}\text { Telomerase inhibition, } \\
\text { telomere shortening }\end{array}$ & Apoptosis, senescence \\
\hline & Ribozymes & Melanoma & Telomerase inhibition & None \\
\hline & Peptide nucleic acids & $\begin{array}{l}\text { Melanoma and } \\
\text { prostate cancer }\end{array}$ & $\begin{array}{l}\text { Telomerase inhibition, } \\
\text { telomere shortening }\end{array}$ & $\begin{array}{l}\text { Growth arrest, } \\
\text { apoptosis }\end{array}$ \\
\hline \multirow[t]{4}{*}{ hTERT } & Ribozyme & $\begin{array}{l}\text { Breast and ovarian } \\
\text { cancers }\end{array}$ & $\begin{array}{l}\text { Telomerase inhibition, } \\
\text { telomere shortening }\end{array}$ & $\begin{array}{l}\text { Inhibition of } \\
\text { proliferation, apoptosis, } \\
\text { increased sensitivity to } \\
\text { topoisomerase } \\
\text { inhibitors }\end{array}$ \\
\hline & Peptide nucleic acids & Prostate cancer & Telomerase inhibition & Reduced cell survival \\
\hline & Dominant-negative & $\begin{array}{l}\text { Melanoma, breast, } \\
\text { ovarian and colon } \\
\text { cancers }\end{array}$ & $\begin{array}{l}\text { Telomerase inhibition, } \\
\text { telomere shortening }\end{array}$ & $\begin{array}{l}\text { Growth arrest, } \\
\text { apoptosis, increased } \\
\text { sensitivity to cisplatin }\end{array}$ \\
\hline & $\begin{array}{l}\text { Small molecule } \\
\text { (BIBR1532) }\end{array}$ & $\begin{array}{l}\text { Prostate, lung and } \\
\text { breast cancers }\end{array}$ & $\begin{array}{l}\text { Telomerase inhibition, } \\
\text { telomere shortening }\end{array}$ & $\begin{array}{l}\text { Senescence-like growth } \\
\text { arrest }\end{array}$ \\
\hline $\begin{array}{l}\text { Telomeric } \\
\text { G-quadruplex }\end{array}$ & $\begin{array}{l}\text { G-quadruplex ligand } \\
\text { (Acridine compounds) }\end{array}$ & $\begin{array}{l}\text { Breast and vulval } \\
\text { cancers }\end{array}$ & Telomerase inhibition & $\begin{array}{l}\text { Growth arrest, } \\
\text { increased sensitivity to } \\
\text { paclitaxel }\end{array}$ \\
\hline
\end{tabular}


they did not activate RNase-H. Thus, these compounds are not true antisense oligonucleotides, but rather behave like classical active-site enzyme inhibitors, i.e. 'template antagonists'. NP oligonucleotides were employed because they form very stable duplexes with single-stranded RNA, are resistant to nucleases and display a high affinity for nucleic acids, but not proteins. Preliminary results indicated that these oligos do not inhibit telomerase activity in vivo (Pruzan et al. 2002). The same group then tested the anti-telomerase effect of $\mathrm{N}^{\prime} \rightarrow \mathrm{P}^{\prime}$ thio-phosphoramidate oligonucleotides (NPS). Telomerase inhibition occurred 24 $\mathrm{h}$ after transfection of an immortalized human breast epithelial cell line at submolar concentrations (Herbert et al. 2002). Long-term treatment with NPS oligonucleotides resulted in gradual telomere shortening followed by cellular senescence and apoptosis, while the mismatched control compound had no effect on cell proliferation (Herbert et al. 2002). Optimization of the sequence, length and bioavailability resulted in the selection of the novel telomerase template antagonist, GRN163 (Asai et al. 2003). GRN163 inhibited telomerase in various tumor cell lines in the presence and absence of carriers. Tumor cells treated with GRN163 in culture underwent telomere shortening and senescence or apoptosis after a period of time and this generally correlated with initial telomere length. In a prostate cancer xenograft model, parentally administered GRN163 caused suppression of tumor growth. These experiments provided evidence that modified antisense oligonucleotides complementary to hTR could be effective anti-tumoral agents for prostate cancer.

\section{Hammerhead ribozymes}

Hammerhead ribozymes are catalytic antisense RNAs that cleave RNA substrates in a sequence-specific manner. A number of studies on experimental human tumor models have demonstrated the possibility of efficiently inhibiting telomerase activity through the use of ribozyme targeting hTR (Yokoyama et al. 1998, Folini et al. 2002). However, changes in cell proliferation or induction of apoptosis were not always observed.

Hammerhead ribozymes targeting the mRNA of the catalytic telomerase component hTERT have also been generated (Yokoyama et al. 2000, Ludwig et al. 2001, Saretzki et al. 2001). The results demonstrated the ability of these molecules to cleave hTERT mRNA and inhibit telomerase activity in endometrial, breast and ovarian carcinoma cells. Ribozyme-mediated reduction of telomerase activity resulted in inhibition of cell proliferation and induction of apoptosis with or without telomere erosion. Moreover, an increased sensitivity to topoisomerase inhibitors was also observed, suggesting the possibility of combining the ribozyme approach for antitelomerase cancer strategy with chemotherapy.

\section{Peptide nucleic acids}

Peptide nucleic acids (PNAs) are modified oligonucleotides that contain a non-ionic backbone in which the deoxyribose linkages have been replaced by N-(2-aminoethyl) glycine units, making them resistant to degradation. PNAs complementary to both core telomerase components were generated. Norton and coworkers (1996) demonstrated the possibility of inhibiting telomerase activity in cell extract by PNAs complementary to the hTR. However, because the membrane permeability of PNAs is not high, strategies to improve the in vivo uptake have been used. In particular, PNAs have been delivered into intact cells by electroporation, generation of PNADNA complexes or conjugation with transport peptides (Herbert et al. 1999, Shammas et al. 1999, Villa et al. 2000). The treatment of immortal human cells with hTR PNAs was able to reduced telomerase activity, shortened telomeres, reduced colony size and arrested cell proliferation (Shammas et al. 1999). PNA-mediated inhibition of telomerase activity, followed by growth arrest or apoptosis, was also demonstrated in human prostate and melanoma cells (Herbert et al. 1999, Villa et al. 2000).

Recently, PNAs targeting the catalytic subunit hTERT were generated (Huard \& Autexier 2002). hTERT-PNAs were delivered into the cytoplasm of human prostate cancer through the photochemical internalization and HIV-Tat protein-based approaches. After light exposure, cells treated with hTERT-PNA showed a marked inhibition of telomerase activity and a reduced cell survival, which was not observed after treatment with hTERT-PNA alone. Moreover, in a direct comparison, photochemical internalization technology proved to be more efficient at internalizing the hTERT-PNA than an HIV-Tat protein-based approach.

\section{Dominant-negative hTERT}

Dominant-negative hTERT (DN-hTERT) constructs are mutated at critical amino acid residues within the catalytic domain and virtually abolished telomerase activity by competing for binding to other components of the telomerase holoenzyme complex that are essential for catalysis. Two independent groups (Hahn et al. 1999, Zhang et al. 1999) have demonstrated the ability of DNhTERT constructs to inhibit telomerase activity in immortalized and tumor cells. Loss of telomerase activity in various human cancer cell lines of different histotypes led to a gradual reduction in telomere length followed by growth arrest or apoptosis, whereas wild-type hTERT transfected cells did not show any changes in telomere length and cell proliferation. Moreover, telomeraseinhibited human cell lines were unable to form tumors when injected into immmunodeficient nude mice, validating telomerase as an important therapeutic target. 
Recently, it has been demonstrated that inhibition of telomerase using the DN-hTERT construct not only limits the growth of tumor cells, but also sensitizes them to anti-neoplastic drugs (Misawa et al. 2002, Tauchi et al. 2002, Tentori et al. 2003). In this context, we recently used the DN-hTERT construct in order to demonstrate the involvement of telomerase in the chemosensitivity of melanoma cells. First, we demonstrated that inactivation of telomerase in melanoma cells, by expressing the DNhTERT construct, induced telomere shortening followed by cellular crisis, demonstrating the role of telomerase on this tumor histotype (Biroccio et al. 2003a). Moreover, inhibition of telomerase increased resistance to temozolomide and increased sensitivity to cisplatin, while there was no change in the response to tamoxifen, indicating that a careful selection of anti-neoplastic agent has to be made when anti-telomerase therapy is combined with chemotherapy (Tentori et al. 2003).

\section{Small molecules}

Nucleoside analogs bind the nucleotide-binding site of reverse transcriptase enzyme and are incorporated into the DNA during the elongation step, thereby interfering with the incorporation of dNTPs. Nucleoside analog inhibitors such as 3-azido-2', 3'-dideoxythymidine (AZT) were among the first synthetic compounds tested against telomerase. However, they only exhibit weak inhibitory activity for human telomerase and mild anti-proliferative capacity (Strahl \& Blackburn 1996, Melana et al. 1998). Chronic treatment of breast cancer cells with AZT induced a senescent phenotype and reduced tumorigenicity only at very high concentrations (Tejera et al. 2001). Novel derivates of 7-deaza-2'-deoxypurine nucleoside triphosphate are much more potent inhibitors of telomerase in vitro (Fletcher et al. 2001).

Non-nucleoside inhibitors bind the hydrophobic pocket near the enzyme's catalytic center, resulting in a conformational change in the active site. BIBR1532 is a novel non-nucleosidic telomerase inhibitor highly specific for telomerase, since it does not seem to affect other DNA and RNA polymerases (Damm et al. 2001). Treatment with BIBR1532 of different human tumor cells, including prostate cancer, led to a progressive telomere shortening followed by senescence-like growth arrest. Telomerase inhibition and telomere shortening also resulted in a marked reduction of the tumorigenic potential of treated cells in a mouse xenograft model.

\section{G-quadruplex DNA-interactive compounds}

DNA sequences that contain stretches of guanine can form four-stranded structures called G-quadruplexes. Potential G-quadruplex-forming sequences are found at telomeres and extend as a single-stranded G-rich 3'-overhang. Molecules capable of interacting with fourstranded G-quadruplex have been generated. These agents are capable of stabilizing the G-quadruplex structure, inhibiting access of telomerase to the telomeres and blocking the elongation step catalyzed by telomerase (Zahler et al. 1991, Mergny et al. 1999). Classes of Gquadruplex inhibitors described to date include antraquinones (Sun et al. 1997, Perry et al. 1998a,b), fluorenones (Perry et al. 1999a), acridines (Harrison et al. 1999), cationic porphyrines (Izbicka et al. 1999, Shi et al. 2001), a perylenetetracarboxylic di-imide derivative (Fedoroff et al. 1998), indolo-quinolines (Caprio et al. 2000) and a benzonaphthofurandione tetracyclic compound (Perry et al. 1999b). However, the development of these Gquadruplex-interacting molecules is severely limited by the relatively poor selectivity for binding to quadruplex versus duplex DNA. This is reflected in these compounds because they showed acute cytotoxicity at concentrations similar to those required for telomerase inhibition. Recently, some other series of potent G-quadruplexinteractive telomerase inhibitors based on ethidium (Koeppel et al. 2001), dibenzophenanthrolines (Mergny et al. 2001), pentacyclic acridines (Gowan et al. 2001, 2002), quinoline (Riou et al. 2002) and the microbial product telomestatin (Shin-ya et al. 2001) have been described. The acridine compounds RHSP4 and BRACO19 are potent cell-free inhibitors of human telomerase and they do not cause non-specific acute cell cytotoxicity at similar concentrations to those required to completely inhibit telomerase activity (Gowan et al. 2001, 2002). The exposure of human cancer cells with short telomeres to non-acute cytotoxic concentrations of both compounds resulted in a marked reduction in cell growth. Moreover, significant anti-tumor activity in vivo was observed when BRACO19 was administered after paclitaxel to mice bearing an advanced stage of vulval carcinoma (Gowan et al. 2002).

\section{Approaches targeting the telomerase regulatory mechanisms}

Recent studies on telomerase regulation showed that telomerase activation is achieved at various steps, including transcriptional and post-transcriptional levels of the hTERT. A number of transcriptional factors, cell cycle inhibitors, cell fate determining molecules, hormone receptors and viral proteins have been implicated in the control of hTERT. Some of the hTERT expression regulators and the main approaches used to inhibit them are reported below and in Table 2 .

\section{Transcriptional factor inhibitors}

A variety of transcriptional factors have been shown to participate in hTERT gene expression (Poole et al. 2001). 
Table 2 Targeting of the telomerase regulatory mechanisms.

\begin{tabular}{|c|c|c|c|c|}
\hline Target & $\begin{array}{l}\text { Therapeutic } \\
\text { approach }\end{array}$ & Tumor type & Molecular effects & Biological effects \\
\hline $\begin{array}{l}\text { Transcriptional factors } \\
\text { c-Myc }\end{array}$ & Gene transfer & Melanoma & $\begin{array}{l}\text { hTERT and telomerase } \\
\text { inhibition, telomere } \\
\text { shortening }\end{array}$ & $\begin{array}{l}\text { Apoptosis, crisis, } \\
\text { increased sensitivity to } \\
\text { cisplatin and } \\
\text { ecteinascidin- } 743\end{array}$ \\
\hline \multirow[t]{2}{*}{ Chromatin } & Demethylating agents & Prostate cancer & $\begin{array}{l}\text { hTERT and telomerase } \\
\text { inhibition }\end{array}$ & Inhibition of proliferation \\
\hline & HDAC inhibitors & $\begin{array}{l}\text { Liver and prostate } \\
\text { cancers }\end{array}$ & $\begin{array}{l}\text { hTERT and telomerase } \\
\text { inhibition }\end{array}$ & Not evaluated \\
\hline Kinases & PCK inhibitors & $\begin{array}{l}\text { Melanoma, naso- } \\
\text { pharyngeal and } \\
\text { cervical cancers }\end{array}$ & Telomerase inhibition & Not evaluated \\
\hline
\end{tabular}

They include Myc (Wang et al. 1998), Sp1 (Kyo et al. 2000), the estrogen and androgen receptors (Misiti et al. 2000, Bosland 2003), E2F-1 (Crowe \& Nguyen 2001), WT-1 (Oh et al. 1999), nuclear factor- $\mathrm{B}$ (Yin et al. 2000) and MZF-2 (Fujimoto et al. 2000). Among them, Myc has been studied in the greatest detail.

The c-Myc oncoprotein has been found to be overexpressed in a wide variety of tumor types including prostate cancers (Dalla-Favera et al. 1982, Cole 1986, Lee et al. 1996). The importance of c-Myc in tumorigenesis has been demonstrated in various experimental studies. However, the mechanisms by which c-Myc participates in tumorigenesis are not yet fully understood. Identification of c-Myc targets, which regulate cell growth, both positively and negatively, may in part explain the role of c-Myc in controlling cell proliferation. The c-Myc oncogene has recently been implicated in the regulation of telomerase through transcriptional activation of telomerase reverse transcriptase, the limiting component for telomerase activity (Weinrich et al. 1997, Bodnar et al. 1998, Vaziri \& Benchimol 1998, Wang et al. 1998, Greenberg et al. 1999, Wu et al. 1999, Kyo et al. 2000). A link between Myc expression and telomerase activity has also been observed in tumors. In particular, hTERT expression correlates with Myc overexpression in prostate, neuroblastoma and cervical cancers (Hiyama et al. 1995b, Latil et al. 2000, Sagawa et al. 2001). In this context, we recently found that c-Myc-dependent telomerase activation plays a crucial role in melanoma tumorigenicity (Biroccio et al. 2002a). In particular, by using melanomaderived clones expressing low levels of c-Myc, we demonstrated that the downregulation of c-Myc reduced cell proliferation rate, cloning efficiency and tumorigenicity and increased the apoptotic rate. Decreased tumorigenic potential correlated with reduced hTERT gene expression, telomerase activity and telomere shortening. Introduction of hTERT into these cells increased their proliferation rate and partially re-established their tumorigenic potential, demonstrating that the reconstitution of high levels of telomerase activity reverses the low tumorigenicity due to low c-Myc expression. By using the same experimental model, we also found that the downregulation of c-Myc oncoprotein decreased the intracellular glutathione content by reducing the expression and activity of $\gamma$-glutamyl-cysteine synthetase, the rate-limiting enzyme for glutathione biosynthesis (Biroccio et al. $2002 b$ ). The two independent c-Myc-mediated biological effects, telomerase dysfunction and oxidative stress, cooperated in inducing cellular crisis (Biroccio et al. 2003a). Concomitantly, we also demonstrated that c-Myc-dependent telomere dysfunction is involved in the increased sensitivity to anti-neoplastic drugs (Biroccio et al. 2003b). In particular, we found that the downregulation of c-Myc increased the susceptibility to cisplatin and to the novel anti-cancer drug ecteinascidin-743. Reconstitution of hTERT in the c-Myc low-expressing clones restored telomerase activity, reduced telomere dysfunction and decreased the sensitivity to both drugs, by enabling the cells to recover from drug-induced $\mathrm{G}_{2} / \mathrm{M}$ block and consequently protecting them from apoptosis.

Together these findings clearly demonstrated that inhibition of c-Myc oncoprotein represents an effective strategy for the treatment of telomerase-positive tumors as a single or combined treatment.

\section{Demethylating agents}

5-Azacytidine is a demethylating agent able to induce gene activation by reverting hypermethylation of altered genes (Jones \& Taylor 1980). The resulting DNA hypomethylation has been linked to the induction of cellular differentiation and altered expression of genes involved in tumor suppression (Herman et al. 1994, 1995, 1996). Demethylating agents have therefore been used as potential anti-neoplastic drugs for some types of tumors, including prostate cancers (Prasanna et al. 1995). 
Guanine methylation/demethylation processes were also considered as modulating hTERT expression regulation, since the promoter of the hTERT gene has a dense CG-rich CpG island (Devereux et al. 1999, Dessain et al. 2000). A positive correlation was observed among hypermethylation of the hTERT promoter, hTERT mRNA expression and telomerase activity (Guilleret et al. 2002). Furthermore, this correlation was confirmed in normal tissues where hypermethylation of the hTERT promoter was found exclusively in hTERT-expressing telomerase-positive samples and was absent in telomerasenegative samples (Guilleret et al. 2002). Moreover, the same group recently demonstrated that demethylation of the hTERT gene promoter by 5-azacytidine reduced hTERT expression, telomerase activity and shortened telomeres (Guilleret \& Benhattar 2003).

The inhibitory effect of 5-azacytidine on telomerase activity has also been demonstrated on prostate tumors (Kitagawa et al. 2000). In particular, treatment of prostate cancer cells with 5-azacytidine significantly reduced telomerase activity and inhibited cell growth. Inhibition of telomerase activity was accompanied by transcriptional downregulation of hTERT mRNA expression. Further analysis seems to indicate that $\mathrm{p} 16$ and c-Myc may play a key role in the 5-azacytidine-mediated transcriptional repression of hTERT (Kitagawa et al. 2000).

\section{Histone deacetylase inhibitors}

Emerging evidence suggests that reversible acetylation/ deacetylation of nucleosomal histones and the resultant changes in the chromatin structure are important processes in gene transcription regulation. Acetylation of histones leads to chromatin decondensation, increasing the accessibility for RNA polymerase complexes. Chromatin remodeling is a dynamic process catalyzed by histone acetyltransferase (HAT) and histone deacetylase (HDAC). Transcription factors, such as Mad, can repress gene expression by recruiting HDACs to specific sites in the gene promoters (Hassig et al. 1997, Laherty et al. 1997). Since hTERT promoter contains Mad-binding sites, histone acetylation may be involved in the transcriptional regulation of hTERT. However, the role of histone acetylation in the regulation of hTERT expression is controversial. It has been demonstrated that tricostatin A (TSA), a potent HDAC inhibitor, was able to reduce telomerase activity in liver and prostate cancers by decreasing the levels of the hTERT mRNA (Suenaga et al. 2002). On the contrary, other groups have shown that TSA induced a significant activation of hTERT mRNA and telomerase activity in telomerase-negative cells (Cong $\&$ Bacchetti 2000) and attenuated the repression of hTERT during HL60 cell differentiation (Xu et al. 2001)

\section{Kinase inhibitors}

Phosphorylation of hTERT protein is one of the mechanisms of hTERT activation. Some protein kinases, such as PKC, involved in several cancer-associated signal transduction pathways, appear to enhance telomerase activity (Li et al. 1998, Kang et al. 1999). On the contrary, protein phosphatase 2A (PP2A) inhibits telomerase activity (Li et al. 1997). On the basis of these findings, kinase-modulating drugs have been used.

In particular, two PKC inhibitors, bis-indolylmaleimide I and $\mathrm{H}-7$, were found to produce a significant inhibition of telomerase activity in nasopharyngeal carcinoma cells ( $\mathrm{Ku}$ et al. 1997) and during $\mathrm{T}$ cell activation (Bodnar et al. 1996). Similar results were obtained in cervical cancer cell lines treated with bisindolylmaleimide I (Kim et al. 2001). The decrease in telomerase activity by PKC inhibition seems to be strictly related to direct or indirect phosphorylation of telomerase proteins, including hTERT. Other PKC inhibitors, such as staurosporine and sphingosine, were less active in decreasing telomerase activity, and other inhibitors, such as quercetin, H-89 and herbimycin A, did not significantly block telomerase activity.

Treatment of human melanoma cells with PP2A decreased telomerase activity, while okadaic acid, an inhibitor of PP2A, stimulated both hTERT phosphorylation and telomerase activity (Kang et al. 1999, Yu et al. 2001).

\section{Approaches targeting telomerase-positive cells}

On the basis that telomerase is typically absent from most normal human cells, but is expressed in nearly all human cancer cells (Kim et al. 1994, Broccoli et al. 1995, Hiyama et al. 1995a), two strategies aimed at targeting telomerasepositive cells have been investigated.

\section{Gene therapy using hTERT promoter}

The promoter of hTERT was used to restrict the expression of therapeutic genes to telomerase-positive cells. In fact, because the hTERT gene is regulated at the transcription level, only tumor cells expressing hTERT would activate the promoter. Much effort has been focused on transferring apoptotic-related genes downstream from the hTERT proximal promoter (from -1 to about 200 to -400 ). It has been reported that transduction of apoptotic genes such as caspase 6,8 (Komata et al. 2001a, 2002), Fas-associated protein with death domain (FADD) (Koga et al. 2001b, Komata 2001b) and bax (Gu et al. 2000, 2002) using the hTERT promoter induced apoptosis in hTERT-positive tumor cells, but not in normal cells or in tumor cells possessing alternative 
mechanisms to lengthening telomeres. Moreover, using these constructs, the growth of tumors in nude mice was significantly suppressed and toxicity prevented.

Interesting results have been obtained using telomerase-specific oncolytic virus (Wirth et al. 2003, Kawashima et al. 2004). The adenoviral vector was able to infect both normal and tumor cells, but only the cells expressing telomerase activity transcriptionally activated the hTERT promoter, permitting viral replication and eventually lysis of cells. Wirth et al. (2003) used a telomerase-dependent conditionally replicating adenovirus (Ad) demonstrating adenoviral replication of hTERT-Ad in all investigated telomerase-positive tumor cell lines but not in telomerasenegative primary human hepatocytes. The capability of hTERT-Ad to induce cytopathic effects in tumor cells was comparable with that of the wild-type adenovirus and significantly higher compared with the oncolytic virus ONYX-015, regardless of the p53 status of the tumor cells, both in vitro and in vivo. Moreover, very recently the effect of a tumor-specific replication competent adenoviral strategy (hTERTp-TRAD) in human cancer cells has been investigated (Kawashima et al. 2004). TRAD induced E1A and E1B adenoviral gene expression in human cancer cells, but not in normal cells such as human fibroblasts. TRAD replicated efficiently and induced marked cell killing in a panel of human cancer cell lines, whereas replication as well as cytotoxicity was highly attenuated in normal human fibroblasts lacking telomerase activity. In mice carrying human lung tumor xenografts, intra-tumoral injection of TRAD resulted in a significant inhibition of tumor growth. No evidence of TRAD was identified in tissues outside of the tumors, despite the presence of TRAD in the circulation. Notwithstanding the good results obtained with the intra-tumoral injection of TRAD, systemic hTERTpTRAD could have side-effects on proliferating cells expressing telomerase activity.

\section{hTERT immunotherapy}

The immunological properties of hTERT that have been discovered suggest that the enzyme is also an attractive target for novel immunotherapies against cancer. To date, there are several reports demonstrating anti-hTERT cytotoxic $\mathrm{T}$ lymphocytes (CTL) responses in cancer. In particular, CD8 + CTL specific for hTERT peptides and restricted to major histocompatibility complex (MHC) HLA-A2 lysed telomerase-positive tumors of different histotypes (Vonderheide et al. 1999, Minev et al. 2000, Arai et al. 2001). Interestingly, no CTL effect was found in telomerase-negative cells, cells negative for the human leucocyte antigen-A2 or telomerase-positive CD34+ hematopoietic cells (Vonderheide et al. 1999, Minev et al. 2000). Furthermore, induction of CTL responses and tumor immunity against unrelated tumors using TERT RNA-transfected dendritic cells has been demonstrated (Nair et al. 2000). On the basis of these promising results, a phase I clinical trial was performed to evaluate the clinical and immunological impact of vaccinating advanced cancer patients with the HLA-A2-restricted hTERT I540 peptide (Vonderheide et al. 2004). hTERTspecific $\mathrm{T}$ lymphocytes were induced in four of seven patients with advanced breast or prostate carcinoma after vaccination with dendritic cells pulsed with hTERT peptide. Tetramer-guided high-speed sorting and polyclonal expansion achieved highly enriched populations of hTERT-specific cells that killed tumor cells in an MHCrestricted fashion. Despite concerns about telomerase activity in rare normal cells, no significant toxicity was observed. Partial tumor regression in one patient was associated with the induction of CD8+ tumor-infiltrating lymphocytes.

\section{Conclusions and perspectives}

Different approaches that directly or indirectly target telomerase have been developed in cancer cells.

According to the initial paradigm for telomerase inhibitors, telomerase inhibitors should initially decrease telomerase activity without affecting the growth rate. Decreased proliferation should only be observed when the telomeres reach a critically short length. Therefore, the delay necessary for the anti-proliferative effect should depend on the initial telomere length. In agreement with this assumption, preclinical studies demonstrated that most telomerase inhibitors are effective on a wide variety of malignancies possessing short telomeres. The lag phase between the time at which telomerase is inhibited and the time at which telomeres shortened sufficiently to produce detrimental effects on cancer cells is evidently a serious obstacle for the application of anti-telomerase strategy, especially in tumor cells with long telomeres. Moreover, the long time exposure to anti-telomerase agents can lead to the development of resistant tumor cells through overexpression of telomerase activity or reactivation of alternative telomere-lengthening mechanisms. One way to overcome this limitation is by combining telomerase inhibition with DNA-damaging chemotherapeutic drugs. Different groups, including ours, have found an enhanced sensitivity of telomerase-inhibited cancer cells to common chemotheraputic drugs, suggesting that combining antitelomerase strategies with chemotherapy could efficiently improve the response of tumors.

Recent findings demonstrated that changes in telomere uncapping versus capping status might be as important as actual telomere length in determining cell survival or death. Great effort has therefore been focused 
on the development of new agents that directly induce telomere dysfunction. The most important advantage in the use of telomere interacting molecules, rather than telomerase inhibitors, is the possibility of obtaining an anti-cancer effect in both telomerase-positive and telomerase-negative tumor cells with long telomeres. However, it must be pointed out that an anti-telomere approach might be more risky, as it may more readily affect telomerase-negative somatic cells.

To date, the most promising strategy for telomerase inhibition seems to be the disruption of telomere capping by telomerase. It has been reported that telomerase, taking part in telomere capping, can regulate cell survival independent of telomerase activity. This approach might even work in tumors with long telomeres, maintaining the specificity against tumor versus normal cells. Thus, a better understanding of the functions of telomerase, as distinct from its telomere-elongating role, should give rise to a completely new generation of telomerase inhibition approaches.

\section{Acknowledgements}

We thank Mrs Adele Petricca for her helpful assistance in typing the manuscript and Mrs Paula Franke for language revision. Work performed in the Experimental Chemotherapy Laboratory was supported by AIRC (Italian Association for Cancer Reserch) and the Ministero della Salute.

\section{References}

Arai J, Yasukawa M, Ohminami H, Kakimoto M, Hasegawa A \& Fujita S 2001 Identification of human telomerase reverse transcriptase-derived peptides that induce HLA-A24restricted antileukemia cytotoxic T lymphocytes. Blood $\mathbf{9 7}$ 2903-2907.

Asai A, Oshima Y, Yamamoto Y, Uochi TA, Kusaka H, Akinaga S, Yamashita Y, Pongracz K, Pruzan R, Wunder E, Piatyszek M, Li S, Chin AC, Harley CB \& Gryaznov S 2003 A novel telomerase template antagonist (GRN163) as a potential anticancer agent. Cancer Research 63 3931-3939.

Bakin RE, Gioeli D, Sikes RA, Bissonette EA \& Weber MJ 2003 Constitutive activation of the Ras/mitogen-activated protein kinase signaling pathway promotes androgen hypersensitivity in $\mathrm{LNCaP}$ prostate cancer cells. Cancer Research $\mathbf{6 3}$ 1981-1989.

Bernard D, Pourtier-Manzanedo A, Gil J \& Beach DH 2003 Myc confers androgen-independent prostate cancer cell growth. Journal of Clinical Investigation 112 1724-1731.

Biroccio A, Amodei S, Benassi B, Scarsella M, Cianciulli A, Mottolese M, Del Bufalo D, Leonetti C \& Zupi G $2002 a$ Reconstitution of hTERT restores tumorigenicity in melanoma-derived c-Myc low-expressing clones. Oncogene 21 3011-3019.
Biroccio A, Benassi B, Filomeni G, Amodei S, Marchini S, Chiorino G, Rotilio G, Zupi G \& Ciriolo MR $2002 b$ Glutathione influences c-Myc-induced apoptosis in M14 human melanoma cells. Journal of Biological Chemistry 277 43763-43770.

Biroccio A, Amodei S, Antonelli A, Benassi B \& Zupi G $2003 a$ Inhibition of c-Myc oncoprotein limits the growth of human melanoma cells by inducing cellular crisis. Journal of Biological Chemistry 278 35693-35701.

Biroccio A, Gabellini C, Amodei S, Benassi B, Del Bufalo D, Elli R, Antonelli A, D'Incalci M \& Zupi G $2003 b$ Telomere dysfunction increases cisplatin and ecteinascidin-743 sensitivity of melanoma cells. Molecular Pharmacology 63 632-638.

Bodnar AG, Kim NW, Effros RB \& Chiu CP 1996 Mechanism of telomerase induction during T cell activation. Experimental Cell Research 228 58-64.

Bodnar AG, Ouellette M, Frolkis M, Holt SE, Chiu CP, Morin GB, Harley CB, Shay JW, Lichtsteiner S \& Wright WE 1998 Extension of life-span by introduction of telomerase into normal human cells. Science 279 349-352.

Bosland M 2003 In vivo regulation of hTERT expression and telomerase activity by androgen. Urologic Oncology: Seminars and Original Investigations 21416.

Broccoli D, Young JW \& de Lange T 1995 Telomerase activity in normal and malignant hematopoietic cells PNAS 92 9082-9086.

Caprio V, Guyen B, Opoku-Boahen Y, Mann J, Gowan SM, Kelland LM, Read MA \& Neidle S 2000 A novel inhibitor of human telomerase derived from 10H-indolo[3,2-b]quinoline. Bioorganic and Medicinal Chemistry Letters 10 2063-2066.

Cole MD 1986 The myc oncogene: its role in transformation and differentiation. Annual Review of Genetics 20 361-384.

Cong YS \& Bacchetti S 2000 Histone deacetylation is involved in the transcriptional repression of hTERT in normal human cells Journal of Biological Chemistry 275 35665-35668.

Crowe DL \& Nguyen DC $2001 \mathrm{Rb}$ and E2F-1 regulate telomerase activity in human cancer cells. Biochimica et Biophysica Acta 1518 1-6.

Culig Z, Hoffmann J, Erdel M, Eder IE, Hobisch A, Hittmair A, Bartsch G, Utermann G, Schneider MR, Parczyk K \& Klocker H 1999 Switch from antagonist to agonist of the androgen receptor bicalutamide is associated with prostate tumour progression in a new model system. British Journal of Cancer 81 242-251.

Dalla-Favera R, Bregni M, Erikson J, Patherson D, Gallo RC \& Croce CM 1982 Human c-myc oncogene is located on the region of chromosome 8 that is translocated in Burkitt lymphoma cells. PNAS 79 7824-7827.

Damm K, Hemmann U, Garin-Chesa P, Hauel N, Kauffmann I, Priepke H, Niestroj C, Daiber C, Enenkel B, Guilliard B, Lauritsch I, Muller E, Pascolo E, Sauter G, Pantic M, Martens UM, Wenz C, Lingner J, Kraut N, Rettig WJ \& Schnapp A 2001 A highly selective telomerase inhibitor limiting human cancer cell proliferation. EMBO Journal 20 6958-6968.

Denmeade SR \& Isaacs JT 2002 A history of prostate cancer treatment. Nature Reviews Cancer 2 389-396. 
Dessain SK, Yu H, Reddel RR, Beijersbergen RL \& Weinberg RA 2000 Methylation of the human telomerase gene CpG island. Cancer Research 60 537-541.

Devereux TR, Horikawa I, Anna CH, Annab LA, Afshari CA \& Barrett JC 1999 DNA methylation analysis of the promoter region of the human telomerase reverse transcriptase (hTERT) gene. Cancer Research 59 6087-6090

Fedoroff OY, Salazar M, Han H, Chemeris VV, Kerwin SM \& Hurley LH 1998 NMR-based model of a telomeraseinhibiting compound bound to G-quadruplex DNA. Biochemistry 37 12367-12374.

Feldman BJ \& Feldman D 2001 The development of androgenindependent prostate cancer. Nature Reviews Cancer 1 34-45.

Feng J, Funk WD, Wang SS, Weinrich SL, Avilion AA, Chiu CP, Adams RR, Chang E, Allsopp RC, Yu J, Le S, West MD, Harley CB, Andrews WH, Greider CW \& Villeponteau B 1995 The RNA component of human telomerase. Science $\mathbf{2 6 9}$ 1236-1241.

Fletcher TM, Cathers BE, Ravikumar KS, Mamiya BM \& Kerwin SM 2001 Inhibition of human telomerase by 7-deaza$2^{\prime}$-deoxyguanosine nucleoside triphosphate analogs: potent inhibition by 6-thio-7-deaza-2'-deoxyguanosine $5^{\prime}$ triphosphate. Bioorganic Chemistry 29 36-55.

Folini M, Pennati M \& Zaffaroni N 2002 Targeting human telomerase by antisense oligonucleotides and ribozymes Current Medicinal Chemistry - Anti-Cancer Agents 2 605-612.

Fujimoto K, Kyo S, Takakura M, Kanaya T, Kitagawa Y, Itoh H, Takahashi M \& Inoue M 2000 Identification and characterization of negative regulatory elements of the human telomerase catalytic subunit (hTERT) gene promoter: possible role of MZF-2 in transcriptional repression of hTERT. Nucleic Acids Research 28 2557-2562.

Gioeli D, Mandell JW, Petroni GR, Frierson HF Jr \& Weber MJ 1999 Activation of mitogen-activated protein kinase associated with prostate cancer progression. Cancer Research 5 9279-9284.

Goueli BS \& Janknecht R 2004 Upregulation of the catalytic telomerase subunit by the transcription factor ER81 and oncogenic HER2/Neu, Ras, or Raf. Molecular and Cellular Biology 24 25-35.

Gowan SM, Heald R, Stevens MF \& Kelland LR 2001 Potent inhibition of telomerase by small-molecule pentacyclic acridines capable of interacting with G-quadruplexes. Molecular Pharmacology 60 981-988.

Gowan SM, Harrison JR, Patterson L, Valenti M, Read MA, Neidle S \& Kelland LR 2002 A G-quadruplex-interactive potent small-molecule inhibitor of telomerase exhibiting in vitro and in vivo antitumor activity. Molecular Pharmacology 61 1154-1162.

Greenberg RA, O'Hagan RC, Deng H, Xiao Q, Hann SR, Adams RR, Lichtsteiner S, Chin L, Morin GB \& DePinho RA 1999 Telomerase reverse transcriptase gene is a direct target of c-Myc but is not functionally equivalent in cellular transformation. Oncogene 18 1219-1226.

Gregory CW, Johnson RT Jr, Mohler JL, French FS \& Wilson EM 2001 $a$ Androgen receptor stabilization in recurrent prostate cancer is associated with hypersensitivity to low androgen. Cancer Research 61 2892-2898.
Gregory CW, He B, Johnson RT, Ford OH, Mohler JL, French FS \& Wilson EM 2001b A mechanism for androgen receptor-mediated prostate cancer recurrence after androgen deprivation therapy. Cancer Research $\mathbf{6 1}$ 4315-4319.

Gu J, Kagawa S, Takakura M, Kyo S, Inoue M, Roth JA \& Fang B 2000 Tumor-specific transgene expression from the human telomerase reverse transcriptase promoter enables targeting of the therapeutic effects of the Bax gene to cancers. Cancer Research 60 5359-5364.

Gu J, Andreeff M, Roth JA \& Fang B 2002 hTERT promoter induces tumor-specific Bax gene expression and cell killing in syngenic mouse tumor model and prevents systemic toxicity. Gene Therapy 9 30-37.

Guilleret I \& Benhattar J 2003 Demethylation of the human telomerase catalytic subunit (hTERT) gene promoter reduced hTERT expression and telomerase activity and shortened telomeres. Experimental Cell Research 289 326-334.

Guilleret I, Yan P, Grange F, Braunschweig R, Bosman FT \& Benhattar J 2002 Hypermethylation of the human telomerase catalytic subunit (hTERT) gene correlates with telomerase activity. International Journal of Cancer 101 335-341.

Hahn WC, Stewart SA, Brooks MW, York SG, Eaton E, Kurachi A, Beijersbergen RL, Knoll JH, Meyerson M \& Weinberg RA 1999 Inhibition of telomerase limits the growth of human cancer cells. Nature Medicine 5 1164-1170.

Hara T, Miyazaki J, Araki H, Yamaoka M, Kanzaki N, Kusaka M \& Iyamoto M 2003 Novel mutations of androgen receptor: a possible mechanism of bicalutamide withdrawal syndrome. Cancer Research 63 149-153.

Harrington L, McPhail T, Mar V, Zhou W, Oulton R, Bass MB, Arruda I \& Robinson MO 1997 A mammalian telomeraseassociated protein. Science 275 973-977.

Harrison RJ, Gowan SM, Kelland LR \& Neidle S 1999 Human telomerase inhibition by substituted acridine derivatives. Bioorganic and Medicinal Chemistry Letters 9 2463-2468.

Hassig CA, Fleischer TC, Billin AN, Schreiber SL \& Ayer DE 1997 Histone deacetylase activity is required for full transcriptional repression by $\mathrm{mSin} 3 \mathrm{~A}$. Cell 89 341-347.

Herbert B, Pitts AE, Baker SI, Hamilton SE, Wright WE, Shay JW \& Corey DR 1999 Inhibition of human telomerase in immortal human cells leads to progressive telomere shortening and cell death. PNAS 96 14276-14281.

Herbert BS, Pongracz K, Shay JW, Gryaznov SM \& SheaHerbert B 2002 Oligonucleotide N3' $\rightarrow$ P5' phosphoramidates as efficient telomerase inhibitors. Oncogene 21 638-642.

Herman JG, Latif F, Weng Y, Lerman MI, Zbar B, Liu S, Samid D, Duan DSR, Gnarra JR, Linehan WM \& Baylin SB 1994 Silencing of the VHL gene by DNA methylation in renal carcinoma. PNAS 91 9700-9704.

Herman JG, Merlo A, Mao L, Lapidus RG, Issa JP, Davidson NE, Sidransky D \& Baylin SB 1995 Inactivation of the CDKN2/p16/MTS1 gene is frequently associated with aberrant DNA methylation in all common human cancers. Cancer Research 55 4525-4530.

Herman JG, Jen J, Merlo A \& Baylin SB 1996 Hypermethylation-associated inactivation indicates a tumor suppressor role for p15INK4B1. Cancer Research 56 722-727. 
Hiyama K, Hiyama E, Ishioka S, Yamakido M, Inai K, Gazdar AF, Piatyszek MA \& Shay JW $1995 a$ Telomerase activity in small-cell and non-small-cell lung cancers. Journal of the National Cancer Institute 87 895-902.

Hiyama E, Hiyama K, Yokoyama T, Matsuura Y, Piatyszek MA \& Shay JW 1995b Correlating telomerase activity levels with human neuroblastoma outcomes. Nature Medicine 1 249-255.

Huard S \& Autexier C 2002 Targeting human telomerase in cancer therapy. Current Medicinal Chemistry - Anti-Cancer Agents 2 577-587.

Iczkowski KA, Pantazis CG, McGregor DH, Wu Y \& Tawfik OW 2002 Telomerase reverse transcriptase subunit immunoreactivity: a marker for high-grade prostate carcinoma. Cancer 95 2487-2493.

Iczkowski KA, Huang W, Mazzucchelli R, Pantazis CG, Stevens GR \& Montironi R 2004 Androgen ablation therapy for prostate carcinoma suppresses the immunoreactive telomerase subunit hTERT. Cancer 100 294-299.

Izbicka E, Wheelhouse RT, Raymond E, Davidson KK, Lawrence RA, Sun D, Windle BE, Hurley LH \& Von Hoff DD 1999 Effects of cationic porphyrins as G-quadruplex interactive agents in human tumor cells. Cancer Research 59 639-644.

Jones PA \& Taylor SM 1980 Cellular differentiation, cytidine analogs and DNA methylation. Cell 20 85-93.

Kamradt J, Drosse C, Kalkbrenner S, Rohde V, Lensch R, Lehmann J, Fixemer T, Bonkhoff H, Stoeckle M \& Wullich B 2003 Telomerase activity and telomerase subunit gene expression levels are not related in prostate cancer: a real-time quantification and in situ hybridization study. Laboratory Investigation 83 623-633.

Kang SS, Kwon T, Kwon DY \& Do SI 1999 Akt protein kinase enhances human telomerase activity through phosphorylation of telomerase reverse transcriptase subunit. Journal of Biological Chemistry 274 13085-13090.

Kawashima T, Kagawa S, Kobayashi N, Shirakiya Y, Umeoka T, Teraishi F, Taki M, Kyo S, Tanaka N \& Fujiwara T 2004 Telomerase-specific replication - selective virotherapy for human cancer. Clinical Cancer Research 10 285-292.

Kim NW, Piatyszek MA, Prowse KR, Harley CB, West MD, Ho PL, Coviello GM, Wright WE, Weinrich SL \& Shay JW 1994 Specific association of human telomerase activity with immortal cells and cancer. Science 266 2011-2015.

Kim YW, Hur SY, Kim TE, Lee JM, Namkoong SE, Ki IK \& Kim JW 2001 Protein kinase C modulates telomerase activity in human cervical cancer cells. Experimental and Molecular Medicine 33 156-163.

Kitagawa Y, Kyo S, Takakura M, Kanaya T, Koshida K, Namiki M \& Inoue M 2000 Demethylating reagent 5-azacytidine inhibits telomerase activity in human prostate cancer cells through transcriptional repression of hTERT. Clinical Cancer Research 6 2868-2875.

Koeppel F, Riou JF, Laoui A, Mailliet P, Arimondo PB, Labit D, Petitgenet O, Helene C \& Mergny JL 2001 Ethidium derivatives bind to G-quartets, inhibit telomerase and act as fluorescent probes for quadruplexes. Nucleic Acids Research 29 1087-1096.
Koga S, Kondo Y, Komata T \& Kondo S 2001a Treatment of bladder cancer cells in vitro and in vivo with 2-5A antisense telomerase RNA. Gene Therapy 8 654-658.

Koga S, Hirohata S, Kondo Y, Komata T, Takakura M, Inoue M, Kyo S \& Kondo S 2001b FADD gene therapy using the human telomerase catalytic subunit (hTERT) gene promoter to restrict induction of apoptosis to tumors in vitro and in vivo. Anticancer Research 21 1937-1943.

Koivisto P, Kononen J, Palmberg C, Tammela T, Hyytinen E, Isola J, Trapman J, Cleutjens K, Noordzij A, Visakorpi T \& Kallioniemi OP 1997 Androgen receptor gene amplification: a possible molecular mechanism for androgen deprivation therapy failure in prostate cancer. Cancer Research $\mathbf{5 7}$ 314-319.

Komata T, Kondo Y, Koga S, Ko SC, Chung LW \& Kondo S 2000 Combination therapy of malignant glioma cells with 2-5A-antisense telomerase RNA and recombinant adenovirus p53. Gene Therapy 7 2071-2079.

Komata T, Kondo Y, Kanzawa T, Hirohata S, Koga S, Sumiyoshi H, Srinivasula SM, Barna BP, Germano IM, Takakura M, Inoue M, Alnemri ES, Shay JW, Kyo S \& Kondo S 2001a Treatment of malignant glioma cells with the transfer of constitutively active caspase- 6 using the human telomerase catalytic subunit (human telomerase reverse transcriptase) gene promoter. Cancer Research 61 5796-5802.

Komata T, Koga S, Hirohata S, Takakura M, Germano IM, Inoue M, Kyo S, Kondo S \& Kondo Y 2001b A novel treatment of human malignant gliomas in vitro and in vivo: FADD gene transfer under the control of the human telomerase reverse transcriptase gene promoter. International Journal of Oncology 19 1015-1020.

Komata T, Kondo Y, Kanzawa T, Ito H, Hirohata S, Koga S, Sumiyoshi H, Takakura M, Inoue M, Barna BP, Germano IM, Kyo S \& Kondo S 2002 Caspase-8 gene therapy using the human telomerase reverse transcriptase promoter for malignant glioma cells. Human Gene Therapy 10 1015-1025.

Kondo S, Kondo Y, Li G, Silverman RH \& Cowell JK 1998 Targeted therapy of human malignant glioma in a mouse model by 2-5A antisense directed against telomerase RNA. Oncogene 16 3323-3330.

Kondo Y, Koga S, Komata T \& Kondo S 2000 Treatment of prostate cancer in vitro and in vivo with 2-5A-anti-telomerase RNA component. Oncogene 19 2205-2211.

Kondo Y, Komata T \& Kondo S 2001 Combination therapy of 2-5A antisense against telomerase RNA and cisplatin for malignant gliomas. International Journal of Oncology 18 1287-1292.

Ku WC, Cheng AJ \& Wang TC 1997 Inhibition of telomerase activity by PKC inhibitors in human nasopharyngeal cancer cells in culture. Biochemical and Biophysical Research Communications 241 730-736.

Kushner DM, Paranjape JM, Bandyopadhyay B, Cramer H, Leaman DW, Kennedy AW, Silverman RH \& Cowell JK 2000 2-5A antisense directed against telomerase RNA produces apoptosis in ovarian cancer cells. Gynecologic Oncology 76 183-192.

Kyo S, Takakura M, Taira T, Kanaya T, Itoh H, Yutsudo M, Ariga H \& Inoue M $2000 \mathrm{Sp} 1$ cooperates with c-Myc to activate transcription of the human telomerase reverse 
transcriptase gene (hTERT). Nucleic Acids Research $\mathbf{2 8}$ 669-677.

Laherty CD, Yang WM, Sun JM, Davie JR, Seto E \& Eisenman RN 1997 Histone deacetylases associated with the mSin3 corepressor mediate mad transcriptional repression. Cell 89 349-356.

Latil A, Vidaud D, Valeri A, Fournier G, Vidaud M, Lidereau R, Cussenot O \& Biache I 2000 htert expression correlates with MYC over-expression in human prostate cancer. International Journal of Cancer 89 172-176.

Lee LA, Dolde C, Barrett J, Wu CS \& Dang CV 1996 A link between c-Myc-mediated transcriptional repression and neoplastic transformation. Journal of Clinical Investigation 97 $1687-1695$

Li H, Zhao LL, Funder JW \& Liu JP 1997 Protein phosphatase 2A inhibits nuclear telomerase activity in human breast cancer cells. Journal of Biological Chemistry 272 16729-16732.

Li H, Zhao L, Yang Z, Funder JW \& Liu JP 1998 Telomerase is controlled by protein kinase Calpha in human breast cancer cells. Journal of Biological Chemistry 273 33436-33442.

Lin Y, Uemura H, Fujinami K, Hosaka M, Harada M \& Kubota Y 1997 Telomerase activity in primary prostate cancer. Journal of Urology 15 1161-1165.

Linja MJ, Savinainen KJ, Saramaki OR, Tammela TL, Vessella RL \& Visakorpi T 2001 Amplification and overexpression of androgen receptor gene in hormone-refractory prostate cancer. Cancer Research 61 3550-3555.

Ludwig A, Saretzki G, Holm PS, Tiemann F, Lorenz M, Emrich T, Harley CB \& von Zglinicki T 2001 Ribozyme cleavage of telomerase mRNA sensitizes breast epithelial cells to inhibitors of topoisomerase. Cancer Research 61 3053-3061.

McDonnell TJ, Troncoso P, Brisbay SM, Logothetis C, Chung LW, Hsieh JT, Tu SM \& Campbell ML 1992 Expression of the protooncogene bcl-2 in the prostate and its association with emergence of androgen-independent prostate cancer. Cancer Research 52 6940-6944.

McElligott R \& Wellinger RJ 1997 The terminal DNA structure of mammalian chromosomes. EMBO Journal 16 3705-3714.

Makarov VL, Hirose Y \& Langmore JP 1997 Long G tails at both ends of human chromosomes suggest a $\mathrm{C}$ strand degradation mechanism for telomere shortening. Cell $\mathbf{8 8}$ 657-666.

Mandal M \& Kumar R 1997 Bcl-2 modulates telomerase activity. Journal of Biological Chemistry 272 14183-14187.

Melana SM, Holland JF \& Pogo BG 1998 Inhibition of cell growth and telomerase activity of breast cancer cells in vitro by 3 '-azido-3'-deoxythymidine. Clinical Cancer Research $\mathbf{4}$ 693-696.

Mergny JL, Mailliet P, Lavelle F, Riou JF, Laoui A \& Helene C 1999 The development of telomerase inhibitors: the G-quartet approach. Anti Cancer Drug Design 14 327-339.

Mergny JL, Lacroix L, Teulade-Fichou MP, Hounsou C, Guittat L, Hoarau M, Arimondo PB, Vigneron JP, Lehn JM, Riou JF, Garestier T \& Helene C 2001 Telomerase inhibitors based on quadruplex ligands selected by a fluorescence assay. PNAS $983062-3067$.

Minev B, Hipp J, Firat H, Schmidt JD, Langlade-Demoyen P \& Zanetti M 2000 Cytotoxic T cell immunity against telomerase reverse transcriptase in humans. PNAS 97 4796-4801.
Misawa M, Tauchi T, Sashida G, Nakajima A, Abe K, Ohyashiki JH \& Ohyashiki K 2002 Inhibition of human telomerase enhances the effect of chemotherapeutic agents in lung cancer cells. International Journal of Oncology 21 1087-1092.

Misiti S, Nanni S, Fontemaggi G, Cong YS, Wen J, Hirte HW, Piaggio G, Sacchi A, Pontecorvi A, Bacchetti S \& Farsetti A 2000 Induction of hTERT expression and telomerase activity by estrogens in human ovary epithelium cells. Molecular and Cellular Biology 20 3764-3771.

Miyake H, Tolcher A \& Gleave ME 1999 Antisense Bcl-2 oligodeoxynucleotides inhibit progression to androgenindependence after castration in the Shionogi tumor model. Cancer Research 59 4030-4034.

Miyake H, Hara I, Kamidono S \& Gleave ME 2001 Novel therapeutic strategy for advanced prostate cancer using antisense oligodeoxynucleotides targeting anti-apoptotic genes upregulated after androgen withdrawal to delay androgen-independent progression and enhance chemosensitivity. International Journal of Urology 8 337-349.

Mukai S, Kondo Y, Koga S, Komata T, Barna BP \& Kondo S 2000 2-5A antisense telomerase RNA therapy for intracranial malignant gliomas. Cancer Research 60 4461-4467.

Nair SK, Heiser A, Boczkowski D, Majumdar A, Naoe M, Lebkowski JS, Vieweg J \& Gilboa E 2000 Induction of cytotoxic $\mathrm{T}$ cell responses and tumor immunity against unrelated tumors using telomerase reverse transcriptase RNA transfected dendritic cells. Nature Medicine 6 1011-1017.

Nakamura TM, Morin GB, Chapman KB, Weinrich SL, Andrews WH, Lingner J, Harley CB \& Cech TR 1997 Telomerase catalytic subunit homologs from fission yeast and human. Science 277 955-959.

Norton JC, Piatyszek MA, Wright WE, Shay JW \& Corey DR 1996 Inhibition of human telomerase activity by peptide nucleic acids. Nature Biotechnology 14 615-619.

Nupponen NN \& Visakorpi T 2000 Molecular cytogenetics of prostate cancer. Microscopy Research and Technique $\mathbf{5 1}$ 456-463.

Nupponen NN, Kakkola L, Koivisto P \& Visakorpi T 1998 Genetic alterations in hormone-refractory recurrent prostate carcinomas. American Journal of Pathology 153 141-148.

Oh S, Song Y, Yim J \& Kim TK 1999 The Wilms' tumor 1 tumor suppressor gene represses transcription of the human telomerase reverse transcriptase gene. Journal of Biological Chemistry 274 37473-37478.

Perry PJ, Gowan SM, Reszka AP, Polucci P, Jenkins TC, Kelland LR \& Neidle S 1998 a 1,4- and 2,6-disubstituted amidoanthracene-9,10-dione derivatives as inhibitors of human telomerase. Journal of Medicinal Chemistry $\mathbf{4 1}$ 3253-3260.

Perry PJ, Reszka AP, Wood AA, Read MA, Gowan SM, Dosanjh HS, Trent JO, Jenkins TC, Kelland LR \& Neidle S $1998 b$ Human telomerase inhibition by regioisomeric disubstituted amidoanthracene-9,10-diones. Journal of Medicinal Chemistry 41 4873-4884.

Perry PJ, Read MA, Davies RT, Gowan SM, Reszka AP, Wood AA, Kelland LR \& Neidle S 1999 a 2,7-Disubstituted amidofluorenone derivatives as inhibitors of human telomerase. Journal of Medicinal Chemistry 42 2679-2684. 
Perry PJ, Gowan SM, Read MA, Kelland LR \& Neidle S $1999 b$ Design, synthesis and evaluation of human telomerase inhibitors based upon a tetracyclic structural motif. Anti Cancer Drug Design 14 373-382.

Poole JC, Andrews LG \& Tollefsbol TO 2001 Activity, function, and gene regulation of the catalytic subunit of telomerase (hTERT). Gene 269 1-12.

Prasanna P, Thibault A, Liu L, Weber J \& Samid D 1995 Therapeutic potentials of 5-aza-2'-deoxycytidine on human prostatic cancer cells. Proceedings of the American Association for Cancer Research 36404.

Pruzan R, Pongracz K, Gietzen K, Wallweber G \& Gryaznov S 2002 Allosteric inhibitors of telomerase: oligonucleotide $\mathrm{N} 3^{\prime} \rightarrow \mathrm{P}^{\prime}$ phosphoramidates. Nucleic Acids Research 30 559-568.

Raffo AJ, Perlman H, Chen MW, Day ML, Streitman JS \& Buttyan R 1995 Overexpression of bcl-2 protects prostate cancer cells from apoptosis in vitro and confers resistance to androgen depletion in vivo. Cancer Research 55 4438-4445.

Ravindranath N, Ioffe SL, Marshall GR, Ramaswamy S, Plant TM \& Dym M 2001 Androgen depletion activates telomerase in the prostate of the nonhuman primate, Macaca mulatta. Prostate 49 79-89.

Riou JF, Guittat L, Mailliet P, Laoui A, Renou E, Petitgenet O, Megnin-Chanet F, Helene C \& Mergny JL 2002 Cell senescence and telomere shortening induced by a new series of specific G-quadruplex DNA ligands. PNAS 99 2672-2677.

Sagawa Y, Nishi H, Isaka K, Fujito A \& Takayama M 2001 The correlation of TERT expression with c-myc expression in cervical cancer. Cancer Letters 168 45-50.

Saretzki G, Ludwig A, von Zglinicki T \& Runnebaum IB 2001 Ribozyme-mediated telomerase inhibition induces immediate cell loss but not telomere shortening in ovarian cancer cells. Cancer Gene Therapy 8 827-834.

Shammas MA, Simmons CG, Corey DR \& Shmookler Reis RJ 1999 Telomerase inhibition by peptide nucleic acids reverses 'immortality' of transformed human cells. Oncogene 18 61916200.

Shi DF, Wheelhouse RT, Sun D \& Hurley LH 2001 Quadruplexinteractive agents as telomerase inhibitors: synthesis of porphyrins and structure-activity relationship for the inhibition of telomerase. Journal of Medicinal Chemistry 44 4509-4523.

Shin-ya K, Wierzba K, Matsuo K, Ohtani T, Yamada Y, Furihata K, Hayakawa Y \& Seto H 2001 Telomestatin, a novel telomerase inhibitor from Streptomyces anulatus. Journal of the American Chemical Society 123 1262-1263.

Sommerfeld HJ, Meeker AK, Piatyszek MA, Bova GS, Shay JW \& Coffey DS 1996 Telomerase activity: a prevalent marker of malignant human prostate tissue. Cancer Research $\mathbf{5 6}$ 218-222.

Strahl C \& Blackburn EH 1996 Effects of reverse transcriptase inhibitors on telomere length and telomerase activity in two immortalized human cell lines. Molecular and Cellular Biology 16 53-65.

Suenaga M, Soda H, Oka M, Yamaguchi A, Nakatomi K, Shiozawa K, Kawabata S, Kasai T, Yamada Y, Kamihira S, Tei C \& Kohno S 2002 Histone deacetylase inhibitors suppress telomerase reverse transcriptase mRNA expression in prostate cancer cells. International Journal of Cancer 97 621-625.

Sun D, Thompson B, Cathers BE, Salazar M, Kerwin SM, Trent JO, Jenkins TC, Neidle S \& Hurley LH 1997 Inhibition of human telomerase by a G-quadruplex-interactive compound. Journal of Medicinal Chemistry 40 2113-2116.

Taplin ME, Bubley GJ, Ko YJ, Small EJ, Upton M, Rajeshkumar B \& Balk SP 1999 Selection for androgen receptor mutations in prostate cancers treated with androgen antagonist. Cancer Research 59 2511-2515.

Tauchi T, Nakajima A, Sashida G, Shimamoto T, Ohyashiki JH, Abe K, Yamamoto K \& Ohyashiki K 2002 Inhibition of human telomerase enhances the effect of the tyrosine kinase inhibitor, imatinib, in BCR-ABL-positive leukemia cells. Clinical Cancer Research 8 3341-3347.

Tejera AM, Alonso DF, Gomez DE \& Olivero OA 2001 Chronic in vitro exposure to $3^{\prime}$-azido-2', $3^{\prime}$-dideoxythymidine induces senescence and apoptosis and reduces tumorigenicity of metastatic mouse mammary tumor cells. Breast Cancer Research and Treatment 65 93-99.

Tentori L, Portarena I, Barbarino M, Balduzzi A, Levati L, Vergati M, Biroccio A, Gold B, Lombardi ML \& Graziani G 2003 Inhibition of telomerase increases resistance of melanoma cells to temozolomide, but not to temozolomide combined with poly (adp-ribose) polymerase inhibitor. Molecular Pharmacology 63 192-202.

Vaziri H \& Benchimol S 1998 Reconstitution of telomerase activity in normal human cells leads to elongation of telomeres and extended replicative life span. Current Biology $\mathbf{8}$ 279-282.

Villa R, Folini M, Lualdi S, Veronese S, Daidone MG \& Zaffaroni N 2000 Inhibition of telomerase activity by a cellpenetrating peptide nucleic acid construct in human melanoma cells. FEBS Letters 473 241-248.

Vonderheide RH, Hahn WC, Schultze JL \& Nadler LM 1999 The telomerase catalytic subunit is a widely expressed tumorassociated antigen recognized by cytotoxic $\mathrm{T}$ lymphocytes. Immunity 10 673-679.

Vonderheide RH, Domchek SM, Schultze JL, George DJ, Hoar KM, Chen DY, Stephans KF, Masutomi K, Loda M, Xia Z, Anderson KS, Hahn WC \& Nadler LM 2004 Vaccination of cancer patients against telomerase induces functional antitumor CD8 + T lymphocytes. Clinical Cancer Research 10 828-839.

Wang J, Xie LY, Allan S, Beach D \& Hannon GJ 1998 Myc activates telomerase. Genes and Development 12 1769-1774.

Weinrich SL, Pruzan R, Ma L, Ouellette M, Tesmer VM, Holt SE, Bodnar AG, Lichtsteiner S, Kim NW, Trager JB, Taylor RD, Carlos R, Andrews WH, Wright WE, Shay JW, Harley CB \& Morin GB 1997 Reconstitution of human telomerase with the template RNA component hTR and the catalytic protein subunit hTRT. Nature Genetics 17 498-502.

Wirth T, Zender L, Schulte B, Mundt B, Plentz R, Rudolph KL, Manns M, Kubicka S \& Kuhnel F 2003 A telomerasedependent conditionally replicating adenovirus for selective treatment of cancer. Cancer Research 63 3181-3188.

Wright WE, Tesmer VM, Huffman KE, Levene SD \& Shay JW 1997 Normal human chromosomes have long G-rich 
telomeric overhangs at one end. Genes and Development 11 2801-2809.

Wu KJ, Grandori C, Amacker M, Simon-Vermot N, Polack A, Lingner J \& Dalla-Favera R 1999 Direct activation of TERT transcription by c-MYC. Nature Genetics 21 220-224.

Xu D, Popov N, Hou M, Wang Q, Bjorkholm M, Gruber A, Menkel AR \& Henriksson M 2001 Switch from Myc/Max to Mad1/Max binding and decrease in histone acetylation at the telomerase reverse transcriptase promoter during differentiation of HL60 cells. PNAS 27 3826-3831.

Yatabe N, Kyo S, Kondo S, Kanaya T, Wang Z, Maida Y, Takakura M, Nakamura M, Tanaka M \& Inoue M 2002 2-5A antisense therapy directed against human telomerase RNA inhibits telomerase activity and induces apoptosis without telomere impairment in cervical cancer cells. Cancer Gene Therapy 9 624-630.

Yeh S, Lin HK, Kang HY, Thin TH, Lin MF \& Chang C 1999. From HER2/Neu signal cascade to androgen receptor and its coactivators: a novel pathway by induction of androgen target genes through MAP kinase in prostate cancer cells. PNAS 96 5458-5463.

Yin L, Hubbard AK \& Giardina C 2000 NF-kappa B regulates transcription of the mouse telomerase catalytic subunit. Journal of Biological Chemistry 275 36671-36675.
Yokoyama Y, Takahashi Y, Shinohara A, Lian Z, Wan X, Niwa K \& Tamaya T 1998 Attenuation of telomerase activity by a hammerhead ribozyme targeting the template region of telomerase RNA in endometrial carcinoma cells. Cancer Research 58 5406-5410.

Yokoyama Y, Takahashi Y, Shinohara A, Wan X, Takahashi S, Niwa K \& Tamaya T 2000 The $5^{\prime}$-end of hTERT mRNA is a good target for hammerhead ribozyme to suppress telomerase activity. Biochemical and Biophysical Research Communications 273 316-321.

Yu CC, Lo SC \& Wang TC 2001 Telomerase is regulated by protein kinase C-zeta in human nasopharyngeal cancer cells. Biochemical Journal 355 459-464.

Zahler AM, Williamson JR, Cech TR \& Prescott DM 1991 Inhibition of telomerase by G-quartet DNA structures. Nature 350 718-720.

Zhang X, Mar V, Zhou W, Harrington L \& Robinson MO 1999 Telomere shortening and apoptosis in telomeraseinhibited human tumor cells. Genes and Development $\mathbf{1 3}$ 2388-2399.

Zhao XY, Malloy PJ, Krishnan AV, Swami S, Navone NM, Peehl DM \& Feldman D 2000 Glucocorticoids can promote androgen-independent growth of prostate cancer cells through a mutated androgen receptor. Nature Medicine 6 703-706. 